Prace Literackie LVIII

Wrocław 2018

https://doi.org/10.19195/0079-4767.58.8

\author{
ELŻBIETA LUBCZYŃSKA-JEZIORNA \\ ORCID: 0000-0002-4459-5291 \\ Uniwersytet Wrocławski
}

\title{
Placówka Bolesława Prusa jako przyczynek do charakterystyki sąsiedzkich stosunków z Niemcami w Kronikach Bolesława Prusa. Rekonesans
}

Choć Lalka Bolesława Prusa wywołała burzliwą dyskusję i zupełnie skrajne wartościowania, publicystyczne dokonania pisarza oceniane są jednoznacznie pozytywnie; wskazuje się ponadto na kroniki jako źródło wciąż niewyczerpanej i nieocenionej wiedzy o epoce i jej problamatyce.

O kwestii żydowskiej i niemieckiej naczelny felietonista dziewiętnastowiecznej Warszawy donosił wiele razy i na różne sposoby, nie tylko w kronikach tygodniowych pisanych przez lata dla „Kuriera Warszawskiego”. Jak jednak Prus opisywał wzajemne relacje tych nacji? W jaki sposób osobiste przekonania autora przekładają się na konstrukcję jego powieściowych bohaterów?

Prus nie wpisał się wyraźnie i jednostronnie w masową ówcześnie swoistą nagonkę na „napór niemiecki”. Daleki był od zabarwionych szowinizmem narzekań na panoszących się w miastach i na prowincjach kolonistów niemieckich wykupujących grunty i asymilujących się z miejscową ludnością. Raczej obserwował „wszystko i wszystkich z pobłażliwym spokojem”, nie uznając przy tym „żadnych dogmatów, nie uważając nic za konieczne"1. Przyjął zatem optykę obserwacji, badania faktów, znaną mu dobrze teorię Augusta Comte'a polegającą na dociekaniu, wiązaniu wydarzeń w łańcuch przyczyn i skutków, wnioskowaniu $\mathrm{i}$ - w efekcie - formułowaniu konkretnego programu. Charakterystyczne dla pisarza w wypadku tego sporu o „niemieckość” zdają się często powtarzane przez Prusa słowa: „oba dzienniki [tym samym: obie opcje, oba kierunki, oba stanowiska - E.L.J.] mają słuszność”2. Dostrzegał zatem zagrożenia, lecz widział także

${ }^{1}$ B. Prus, Stówko o krytyce pozytywnej, [w:] idem, Pisma, t. 29. Studia literackie, artystyczne i polemiki, Warszawa 1950, s. 176.

2 B. Prus, Kroniki, oprac. Z. Szweykowski, t. 5, Warszawa 1955-1970, s. 212 n.; w dalszej części odnośnik do tego samego źródła zostanie podany w nawiasie po cytacie — na przykład (K V, 212). 
zalety i mocne strony niemieckich organizacji rolnych i bankowych, formułując przy tym wyraźne postulaty:

Niemcy mają spółki i kapitały do wykupywania ziemi u nas, podczas gdy nasi rolnicy nie posiadają ani potrzebnych im instytucji kredytowych, ani spółek do parcelowania majątków [...], ani rolniczych stowarzyszeń w celu podniesienia gospodarstw.

Niemcy mają szkoły techniczne i wykwalifikowanych przemysłowców i majstrów; my nie mamy takich szkół, a więc brak nam odpowiedniej ilości przemysłowców i majstrów. (K V, 212)

Rzeczowa analiza rzeczywistości, bez emocjonalnej egzaltacji: obserwacja — opis — pomysł. Tak najczęściej jawi się kwestia stosunków z Niemcami w Kronikach, ale nie tylko. Także Placówka pozostała zdystansowana wobec nacjonalistycznych uprzedzeń. Koloniści niemieccy — zbiorowy bohater powieści — nie podlegają negatywnym wartościowaniom. Placówka eksponuje trud ich pracy, docenia organizację i pomysł, silne poczucie wspólnoty rozumianej kategoriami Ferdinanda Tönniesa.

Już Niemcy wozy płótnem kryte uszykowali w kwadrat, tworząc z nich jakby parkan, wewnątrz którego stoi bydło i konie, a zewnątrz kręcą się ludzie. Ten wydobywa przenośny żłób na czterech nóżkach i stawia go przed krowami, inny wsypuje tam obrok z maniaka, inny z wiadrami idzie po wodę do rzeki. Kobiety wynoszą spod płacht żelazne kociołki i woreczki legumin, a gromada dzieci biegnie do jarów po opał ${ }^{3}$.

Naturalna jedność ukonkretnia się tu we wspólnocie terytorium, której wyrazem jest współzamieszkiwanie ${ }^{4}$ — wozy ustawione przez Niemców na planie czworoboku mocno podkreślają osobność świata, kultury i religii, nawet jeżeli tworzą ją w świecie sobie obcym, nieznanym. Ślimaka zdumiewa również umiejętność bycia/życia razem, czerpania wzajemnych korzyści; zadziwia go ta szczególna, bo biologiczna wręcz, symbioza:

jak ony kupą wszystko robią? Przecie i nasi ludzie, bywa, że wyjdą gromadą; ale każdy krząta się sam za siebie, ino częściej odpoczywa albo jeszcze innym przeszkadza. Te zaś psiekrwie tak jakosik zwijają się, jakby jeden nagieniał drugiego. Nie spróżnujesz, choćby cię kładło na ziemię, bo ci jeden tka w garść robotę, a już drugi na nią czeka i pili, żebyś kończył. (P, 146)

Widzi, jak Niemcy

wzajemnie od siebie czerpią korzyści oraz posiadają i użytkują w spólne dobra [wyr. obecne w oryginale], rozumie wtedy wyraźniej, że ma to przekładnię wieloraką: wola posiadania i korzystania to wola opieki i obrony, a wspólne dobra — to wspólne przykrości; wspólni przyjaciele — to wspólni wrogowie 5 .

Chłop definiuje wtedy polskość, dostrzega mimochodem wady Polaków, przywary, które od wieków pozostają jakby te same. Obserwacja prostych czynności staje się dla bohatera Placówki polem do porównań rodzących się niejako

${ }^{3}$ B. Prus, Placówka, oprac. T. Żabski, Wrocław 1987, s. 146; w dalszej części zapis w nawiasie po cytacie — na przykład (P, 146).

${ }^{4}$ Por. F. Tönnies, Teoria wspólnoty, [w:] Wspólnota i stowarzyszenie. Rozprawa o komunizmie i socjalizmie jako empirycznych formach kultury, Warszawa 1988, s. 268.

${ }^{5}$ Ibidem. 
naturalnie - dopiero na tle organizacji i uporządkowania Niemców Ślimak dostrzega polską nieudolność, lenistwo i kłótliwość.

— Wartki naród te Szwaby — mruczał — i mądry...

Sokoli jego [Ślimaka - E.L.J.] wzrok w pół godziny odkrył dwie tajemnice nowożytnej pracy: pośpiech i organizację.

— To ci naród te Szwabska!... Hamery wyglądają na panów, a ci, co wzięli od nas kartofle, na chłopów; przecie jeden drugiemu rękę podaje za pan brat. U nas ludzie jak pogniewają się, to już nie wysłucha jeden drugiego; te zaś pary, choć się gniewają, to zawdy jeden drugiego wyrozumie i zrobi spokój... (P, 146)

Bolesław Prus w maju 1895 roku odbył nieplanowaną i dostarczająca wielu nieoczekiwanych wrażeń podróż do Berlina. Przyczyniła się ona do pogłębionych obserwacji i rozszerzenia spektrum pozytywnych deskrypcji. To, co w Placówce wydawało się jedynie przyczynkiem do charakterystyk niemieckich obyczajów, w listach pisarza i jego Kronikach z końca lat dziewięćdziesiątych znajduje rozwinięcie i reporterskie doświetlenie.

Międzynarodowe stosunki sąsiedzkie powracają w Prusowskiej optyce w wielu kronikach i listach. Różne przejawy życia i kulturowych odmienności wzbudzały ciekawość realisty. Podejmował zatem rozważania dotyczące niemieckiej gospodarności, porządków, praw, ułożenia kundmanów i terminatorów, płodozmianów, systemu szkolnictwa, myśli pedagogicznej. Pisarza interesowały również „sensacyjne procesy o morderstwa" (K XIII, 484), gdyż przy ich okazji poddawał analizom zasady działania niemieckich sądów czy przygotowania niemieckich sędziów do prowadzenia rozpraw. Rozważał, jakie „,daleko idące środki ostrożności przedsięwzięto w różnych krajach Zachodniej Europy”, by zahamować szerzenie się zarazy, i dlaczego adekwatne zarządzenia sanitarne w Królestwie Polskim nie uchroniły jego rodaków przed inwazją cholery, która szybko z Lubelszczyzny przeniosła się na inne gubernie (K XIII, 481).

Prus skrupulatnie analizował także broszury, zatytułowane na przykład O sposobach zrobienia majątku w Królestwie Polskim. W latach osiemdziesiątych pojawiały się one masowo w różnych częściach Niemiec. Stawiał pytania: „dlaczego ci Niemcy, którzy tu przyjeżdżają robią majątki”, a „Warszawa roi się żebrakami i cały kraj narzeka na biedę?” (K XI, 96). Wielokrotnie też pytał: „dlaczego oni, a nie my?!” i zaskakiwał odpowiedzią niewygodną dla czytelników: „gdyż oni lepiej znają Królestwo aniżeli my, którzy nie prowadzimy żadnych rachunków" (K XI, 96). Autor Lalki konstatował:

dwadzieścia trzy lat upłynęło od czasu uwłaszczenia włościan, pomimo to my nic nie wiem, o ile wpłynęło to na podniesienie dobrobytu [...]. Od dawna Niemcy wykupują u nas ziemie i — jak się mówi - przeszkadzają utworzeniu się rodzimego przemysłu. Wydano więc prawa przeciw swobodnej gospodarce cudzoziemców. [...] czy poprawiło to publiczne zdrowie? Czy wzrosła liczba rękodzielników i ludzi z wyższym ukształceniem? Ile ziemi przeszło w ręce niemieckie, a ile w chłopskie? (K XI, 96)

Odpowiedź wydawała się oczywista zarówno dla czytelników współczesnych pisarzowi, jak i nas. „Nasi patrioci p o daw ne mu [wyr. — E.L.J.] wzdychają 
nad nieszczęśliwym położeniem kraju - [...] ale najczulsze westchnienia nie zastąpią statystyk. [...] Niechże was wciórności wezmą z takim patriotyzmem!" (K XI, 97). Patriotyzmem nie jest więc przepędzanie obcych - to ryzykowna teza Prusa. Nie wywołała ona entuzjazmu wśród krytyków kolonizacji. Prus idzie jednak dalej: „wielkim nieszczęściem Poznańskiego jest rząd pruski — ale nie pierwszorzędnym! Pierwszorzędnym złem są wewnętrzne choroby tego społeczeństwa!” (K XI, 67). To diagnozy niepopularne w owych czasach, wykluczające pisarza ze ścisłego grona oponentów kolonizacji.

Przy tej okazji Prus nazywał też relacje z Rosjanami, Żydami, Francuzami, Anglikami, za każdym razem eksponując polską niechęć do sąsiadów wewnątrz i na zewnątrz państwowości pozbawionej przecież śladu na mapach. Zdając relacje z wzajemnych stosunków Polaków z innymi nacjami, wielokrotnie podkreślał lenistwo i niemoc polskiej inteligencji (K XI, 67), które zestawiał z „siłą, pracowitością, oszczędnością i wyższym ucywilizowaniem Niemców" (K VI, 63).

W kwietniu 1888 roku Prus stylizował się na pisarza z innego kręgu kulturowego, ubrał anglosaski garnitur i donosił wyimaginowanemu przyjacielowi o poczynaniach jednego z polskich autorów:

Pewien tutejszy autor napisał kilka lat temu powieść pod tytułem Figa z Makiem czy też Dziura w Moście, usiłując scharakteryzować w niej życie społeczne, stosunki społeczne i typy kilku pokoleń. U nas w Anglii pytano by przede wszystkim: O ile owe typy i stosunki są prawdziwe i o ile nowe? Tu jednak najniecierpliwiej dowiadywano się, dlaczego powieść nosi tytuł Figa z Makiem czy też Dziura w Moście, i czy Dziura ożeni się z Makiem, a Figa z Mostem?... gdyby z góry było wiadome: kto się z kim ożeni i kto za kogo pójdzie, polska powieść nie miałaby czytelników. Dziwny to kraj pod każdym względem. Wszystko wygląda tu jakby było przewrócone do góry nogami. (K XI, 110)

I choć słowa te nie dotyczą stosunków polsko-niemieckich — odnoszą się bowiem bezpośrednio do sporu o powieść i jej zadania, a pisarz stał się tu rzecznikiem antyromansowości literatury we wszystkich jej genologicznych odmianach - mimochodem (a może wcale nie) wypowiedź ta doprecyzowuje geograficzne „tu” i „tam”, kulturowe „my” i „oni”. Staje się tym samym kolejnym dowodem na wyraźny rozbrat oczekiwań, możliwości i działań.

Konstatacją, a może i konsternacją — na fali niechęci do kolonistów niemieckich — staje się jednak stwierdzenie, że Prusy najczęściej jednak autora zachwycały. Wielokrotnie pisał o tym w listach do bliskich od maja 1895 roku:

Prusy zrobiły na mnie silne wrażenie. [...] Ileż tu rzeczy dużych i małych godnych widzenia i naśladowania! ${ }^{6}$

Niemcy są narodem w najwyższym stopniu republikańskim, nie z haseł, ale z charakteru. Porządek i obowiązek wydają się tu tak silnie zakorzenione, że nawet dyrektywy nie potrzeba, co najmniej w życiu codziennym. (L, 215)

Przywoływane przykłady wskazują, iż obserwacje sąsiadów i międzynarodowych relacji służyły Prusowi głównie do porównań — najczęściej bolesnych —

${ }^{6}$ B. Prus, Listy, oprac. K. Tokarzówna, Warszawa 1959, s. 213; w dalszej części zapis w nawiasie po cytacie — na przykład (L, 213). 
humorystycznie bądź satyrycznie wytykających rozmiary nieładu i „skutków braku planów", które pisarzowi w polskiej rzeczywistości najbardziej przeszkadzały:

Owa zagranica strasznie mi oczy otwiera! My strasznie jesteśmy biedni i żyjemy jak krety wobec ucywilizowanego świata. Powtarzam ci: wiedziałem, że zobaczę coś nowego, ale o tylu i takich nowościach nie miałem pojęcia. (L, 214)

W innym miejscu napisał: „wielkość [Prus] przytłacza, a nowość boli” (L, 216-217).

Krytyka - wprost lub pośrednio — społeczeństwa, społeczności, narodowości to nie jedyny komponent swoistego polskiego kodu kulturowego, który możemy wyczytać z Kronik. Wyjątkowo dychotomiczny zdaje się bowiem stosunek Prusa do „zagranicy”, do „niemczyzny”. Kroniki i listy są więc świadectwem sinusoidalnej wariacji nastrojów pisarza - od upojenia wielkością i nowoczesnością do przygnębienia emocjonalnego.

Charakterystyce sąsiadów stale towarzyszy odwołanie do szeroko pojętej polskości:

Gdybyś zaś wiedziała, jacy tu są przystojni mężczyźni. W Warszawie to zdechlaki, a ja najgorszy. Kobiety są mniej ładne i mniej śmiałe (przynajmniej w pozorach - w gruncie bowiem ma tu panować wielka swoboda obyczajów, aż mi się nie chce wierzyć). (L, 220)

Po miesiącu pobytu w Berlinie pisał już o poczuciu osaczenia:

jutro opuszczam to piękne więzienie [...]. Już rozumiem stolicę Niemiec. Miasto piękne, za piękne, ale zimne jak lód. Za miliony nie chciałbym tu mieszkać całe życie. [...] Wybiegam też czasami „na wieś”. Boże, jaka tu wieś pod Berlinem: pałace i kamienice. [...] a co za ruch! Wałęsając się obok kolei obwodowej, rachowałem pociągi: co minutę jeden!... Tu ludzie są uczciwi, dobrzy i nawet grzeczni, ale chyba mają kamienne serca - taki dziwny ich wygląd i zachowanie. Jest to naród, w którym rozwinęła się myśl i wola, ze szkodą dla uczucia. (L, 226-227)

„Wszędzie tu pałace, zamki, pyszne ogrody, a ja - mimo to - zazdroszczę Wam lasu" (L, 228). Podróż do sąsiadów szybko więc staje się dla Prusa pańszczyzną — odrobił ją i chciał szybko wrócić do „swoich”, choć tak często wytykał im wady i nieudolność: „Człowiek, jak ślimak, cierpi, gdy go wydrą z własnej skorupy" (L, 228).

Mimochodem wracamy do ślimaka! Bohater prusowskiej powieści nie jest pewny swoich sądów o Niemcach, nie wie, skąd ten „błędny naród” przybywa i dokąd zmierza, nie analizuje narodowościowych motywacji, wszystkich traktując jednakowo, po ludzku proponuje miejsce do odpoczynku po dalekiej drodze, kromkę chleba i miarkę mleka. Wzbudza tym sprzeciw lokalnej społeczności. Nie rozumie jednak dlaczego. Placówka pozostaje bowiem otwarta na pytania postawione we wstępie, jest prusowskim „nie wiem” o przyszłości relacji sąsiedzkich, kontynuacją niejednoznaczności w ocenie sąsiadów. Przedmiotem powieści ,jest więc nie walka o kobietę, lecz walka o ziemię"7.

\footnotetext{
${ }^{7}$ Cyt. za: I. Franko, O literaturze polskiej, oprac. M. Kuplowski, Kraków 1979, s. 165.
} 
Dojrzały realizm zakładał związek literatury z życiem. Pozytywiści często podkreślali, że ono właśnie dostarcza im wydarzeń przeobrażających się w materiał do schematów fabularnych. Orzeszkowa pisała: „Od pewnego czasu przestałam całkiem fantazjować i potrzebuję koniecznie widzieć, słyszeć, dotknąć się, aby pisać"8. Maksymalne uprawdopodobnienie opisywanych wydarzeń stało się jednym z podstawowych dążeń poetyki realistycznej. Świat przedstawiony miał za zadanie wytworzyć u odbiorców iluzję rzeczywistości ${ }^{9}$. Prus przypatrywał się chłopu w jego chałupie, a kronikarskie rozważania o zalewie kolonistów niemieckich uczynił tematem swej wielkiej powieści, w której teatralizacja świata przedstawionego zasadza się na dialogiczności akcji, bardzo zwartej i silnie zdramatyzowanej budowie, a Niemcy pojawiają się jako osoby dramatu (genologicznie i osobiście). Budowa Placówki jest metodycznie konsekwentna, a jej ramy stanowią: wyraźnie skonstruowana ekspozycja, na którą składają się opis miejsca akcji, prezentacja bohaterów (krótka charakterystyka, codzienne zajęcia i problemy) i wyodrębniony z całości epilog — swoista kontynuacja i przeniesienie losów bohaterów do świata rzeczywistego czytelnika. Martuszewska nazywa ten zabieg dominacją odwołań do czasu i przestrzeni istniejących obiektywnie poza literaturą ${ }^{10}$, zatem do realiów dobrze znanych ówczesnemu czytelnikowi: budowy kolei, napływu niemieckich kolonistów czy sporów o „polskość” i „niemieckość" w warszawskiej prasie lat osiemdziesiątych XIX wieku.

Zawiązaniem powieściowej akcji staje się rozmowa Ślimaka z przejeżdżającymi w pobliżu jego pól Niemcami. Pojawiają się też kolejne obce osoby, które wprowadzają zamęt $\mathrm{w}$ dotychczas monotonne, ale przewidywalne życie gospodarza. Chodzi o mierniczych, na handlu z którymi Ślimak w krótkim czasie się wzbogacił. Jeszcze jedno wydarzenie zachwieje porządkiem codziennych ,pracy i dni" - dziedzic sprzeda majątek, a nowy właściciel — Hamer — będzie konsekwentnie dążyć do odkupienia górki Ślimaka, samotnej, wyjałowionej „wyspy” na urodzajnej ziemi dziedzica.

Ważniejsze z perspektywy interesującej nas tu tematyki okazuje się obserwowanie narastania konfliktu: Niemcy niemal osaczają chłopa, który niczym nie daje zmusić się do sprzedaży kawałka ziemi. Opatrzność zsyła na Ślimaka hiobowe wręcz próby - umiera mu dziecko, drugi syn trafia do więzienia, kradną mu konie, śmiertelnie choruje żona, za jego przyczyną w mroźną noc zamarza bezgranicznie mu oddany sługa i bezbronne dziecko — znajda podrzucona przez „głupią” Zośkę, która w końcu z zemsty podpala chałupę Ślimaka. Sam Ślimak wylicza te nieszczęścia, nie dziwi się jednak — o dziwo! — ich wielkiemu nagromadzeniu. Monolog Ślimaka w pełni bowiem odwzorowuje jego mentalność,

${ }^{8}$ E. Orzeszkowa, Pisma zebrane, red. J. Krzyżanowski, t. 14, Warszawa 1948, s. 224.

9 W. Weintraub, Wyznaczniki stylu realistycznego, ,Pamiętnik Literacki” 52, 1961, nr 2, s. 41 n.

${ }^{10}$ Por. A. Martuszewska, Poetyka polskiej powieści dojrzałego realizmu (1876-1895), Wrocław 1977, s. 82. 
stosunek do sąsiadów. Cały niemal świat chłopa autor mieści w kilku zaledwie zdaniach:

— Hycle Szwaby! Co tu przez nich narodu zmarniało... - mruknął chłop. I ustawiwszy rękę naprzeciw okna, tak, aby dobrze widzieć palce, zaczął rachunek: - Utopił mi się Stasiek, to jeden... Niemce byli przy tym... Musiałem oddać krowę na rzeź, to dwa, bo mi bez Szwabów paszy zabrakło... Konie mi ukradli, to śtyry, za to żem złodziejom odebrał niemieckiego wieprza... Burka struli — to pięć... Jędrka wzięli do sądu za Hermana — to sześć...Owczarz i sierota — to osiem... Osiem narodu zgładzili!... A jeszcze Magda przez nich odejść musiała, bom zbiedniał, i jeszcze mi żona choruje pewno ze zgryzoty, to dziesięć... Chryste Panie!... Chryste Panie!... (P, 247)

Poszczególne sceny dają nam precyzyjny obraz życia codziennego sąsiadujących z sobą Polaków i Niemców. Prus dokładnie opisywał tryb życia i organizację pracy niemieckich kolonistów. Stale dystansował się od podszytej szowinizmem ideologicznej walki z „naporem niemieckim”. Dążył do realistycznego obiektywizmu — wolnego od uprzedzeń i nietolerancji. Pokazywał więc nie realizatorów ostrej polityki Bismarcka, ale ludzi zmuszonych ciężkimi warunkami życia we własnym kraju do poszukiwania ziemi, pracy, do uniknięcia obowiązku służby wojskowej:

My, Niemcy, mamy swój kraj, nawet większy od waszego, ale tam źle. Ludzi dużo, ziemi mało, o zarobek trudno. A jeszcze musim płacić wielkie podatki, a jeszcze w wojsku służba ciężka, a jeszcze rozmaitymi karami okładają człowieka... [...] w naszym kraju jest źle, no więc przychodzimy tu... (P, 144)

\section{Chata Ślimaka to kropla w morzu ludzkich interesów:}

Przy drodze mieszczą się budynki Ślimaka. Jest tam chata zwrócona jednymi drzwiami do gościńca, drugimi do podwórka, jest stajnia z oborą i chlewkiem, nakryte jednym dachem, jest stodoła i wreszcie szopa na wozy. Wszystko ustawione wzdłuż boków kwadratowego dziedzińca. (P, 7)

Zaskakująco paralelna jest ta organizacja budynków i mikrokosmosu: i Polak, i „Niemce” wytyczają granice świata, konstytuują jego filary na planie jakby świętego czworoboku. Placówka obrazuje bowiem archetypiczne pojęcie domu, wskazuje jego wymiar momentalny — sic i nunc — oraz mityczny — „zawsze”. Dla zrozumienia tych kwestii ważne okazuje się odtworzenie położenia domu relacje między tym, co wewnętrzne i zewnętrzne, co daje wnętrze i czym grozi świat zewnętrzny. Te relacje nie zależą od narodowości. Dla obu nacji świat zewnętrzny kształtuje się podobnie — z zewnątrz, poza granicą rozpoznawalnego, a tym samym nazwanego, oswojonego świata, poza „kwadratem zagrody”, poza linią pola znajduje się to, co obce, to, co Ślimak często ogląda, ale granicy czego jakby nie przekracza. To skłania do ujmowania świata w kategoriach sacrum i profanum, które opisał Tadeusz Żabski — badacz ten pokazał, jak w pamięć chłopów został wpisany akt kosmogoniczny, który dokonał swoistej sakralizacji przestrzeni. Ziemię uświęca praca i życie - pokolenia przychodzą i odchodzą, zostawiając po sobie specyficzne, bo niewidzialne granice - prochy przodków uświęcają wycinek rzeczywistości, tradycja uporządkowuje przestrzeń, zapewnia ład i bezpieczeństwo, a swoiste „końce świata”: próg domu, granica pola, 
linia horyzontu wyznaczają ciągłość przestrzeni rozpoznawalnej jako swoja. Gdy Niemcy budują swój świat na obcej ziemi, konstytuują go na tożsamych filarach.

Dom to zatem miejsce, dom to siedziba ludzka — taki oto charakter ma osada Ślimaka i wozy Niemców ustawione na planie czworoboku ${ }^{11}$. Tu i tu mamy do czynienia z chatą — nie ma znaczenia, że u Ślimaka dosłowną, a u Niemców umowną. Obie odgrodzone przestrzenie zostały osadzone na ziemi, w określonym miejscu, we własnym świecie, w zgodzie z tradycją. Możemy obserwować nieprzepartą chęć schronienia się w ich nieprzestronnych wnętrzach - chowa się w niej chory Stasiek, zmęczone zabawą dzieci, „urobiony” Ślimak, chowają się też Niemcy przed nocą, która może przynieść zagrożenie. Dom przybierający znaczenie schronienia kojarzy się ponadto z bliskością ludzi i rzeczy, i zwierząt. Jednocześnie sposoby jego osadzania unifikują obie nacje, zacierają różnice między nimi. Wszak świat naprędce budowany przez sąsiadów-przybyszów jest w zasadzie tożsamy w granicach ze światem dolińskich chłopów.

Dom Ślimaka został usytuowany na pagórku, w związku z czym na sąsiadów chłop spogląda z góry i z oddalenia. Dostęp do chaty zabezpiecza więc odległość i wysokość; dom wyrasta niejako z ziemi - to ziemia jest domem. Takie rozumienie domu koresponduje z ludowym światopoglądem i chłopską kulturą. Szczegółowo pisał o tym Eliade ${ }^{12}$. Ziemia staje się domem, bo - jak wspomnieliśmy - zamieszkują ją duchy przodków, bo predestynuje ją pokrapianie święconą wodą, bo zjednuje ją praca, bo konstytuują ją ,stuletnie dęby — zwycięzcy burz” (P, 98), „ogromne kamienie otoczone kępami traw i mchem porosłe, co gdzieniegdzie drzemią na polach, pilnując granic" (P, 136-137), bo w końcu okalają ją właśnie te niewidoczne granice, które wydobywają ojcowiznę z chaosu, z profanum. Ślimaka i Niemców — mimo wszystkich różnic — łączy silna potrzeba podziału przestrzeni na swoją i obcą — można by użyć tu określenia Anety Mazur i powiedzieć, że obie nacje wpisane są w „kosmogeniczne rysy pejzażu”.

Każdy zna tu swoje miejsce, a wszystko ma swój czas i logiczny porządek. Niemcy w nieznanej sobie przestrzeni szybko tworzą swój świat, nadają mu symboliczne granice, ustawiając wozy w kwadrat, dzielą tym samym przestrzeń na swoją - bezpieczną - i obcą jeszcze — niebezpieczną. Choć stanowią silną — bo odrębną i świetnie zorganizowaną — grupę, są wewnętrznie niejednorodni. U Polaków jest inaczej — każda zagroda jest osobnym światem, odrębnym kwadratem; Placówkowa polskość nie jest wspólnotą. Nawet Ślimak, przestraszony przecież naporem, chaosem, jaki Niemcy wprowadzają w jego poukładany świat,

${ }^{11}$ Istotę takiego ujęcia domu wyjaśnia także Gaston Bachelard; zob. idem, Dom rodzinny i dom oniryczny, [w:] idem, Wyobraźnia poetycka, Warszawa 1975.

12 Zob. M. Eliade, Sacrum, mit, historia. Wybór esejów, Warszawa 1974; ponadto J. Tomicka, R. Tomicki, Drzewo życia. Ludowa wizja świata i człowieka, Warszawa 1975; E. Mieletinski, Poetyka mitu, Warszawa 1981 — prace te stały się podstawą bardzo szczegółowej interpretacji mitu obrony „ziemi świętej” dokonanej przez Tadeusza Żabskiego we Wstępie do Placówki wydanej w serii Biblioteki Narodowej. 
nieświadomie docenia ich zwyczaje. Niemcy nie nawiązują bliższych kontaktów z miejscową ludnością, dziwią się wręcz gościnności Ślimaka, który za chleb i wodę nie chce od nich pieniędzy. U nich nic nie dzieje się bezinteresownie, z czego wywodzą swą ekonomiczną siłę i przez co podporządkowują całą okolicę swoim interesom, odsuwając niezorganizowanych, zawistnych względem siebie chłopów od handlu z budowniczymi kolei, a także opanowują cały rynek pracy, jaki kolej stworzyła. Wygrywają z miejscową ludnością — jak pisze Tadeusz Żabski - w wolnorynkowej ,walce o byt"13. A chłopi swoje przegrane thumaczą nie własną nieudolnością, brakiem chęci do pracy, nieumiejętnością zorganizowania, lecz jakąś straszną według nich potęgą żywiołu niemieckiego, który na mocy niesprawiedliwego prawa uczynił z Niemców sąsiadów. Prus „daje nam tu plastyczny wykład nowożytnej organizacji pracy, w którym pisarz przemawia głównie jako socjolog popularyzator i demonstruje swe poglądy"14. Nie można przy tym oprzeć się wrażeniu, że docenia wartość i sens owego „pośpiechu i organizacji”.

Niechciani sąsiedzi wysadzają jednak przydrożne kamienie — ślady ontologicznej walki aniołów i diabłów, dobra ze złem, która uświęciła ziemię dolińskich chłopów. Niechciani sąsiedzi wycinają wiekowe dęby strzegące pamięci o wisielcach i historiach. „Błędny naród” kwestionuje uświęcone tradycją prawa „autochtonów”, jak o chłopach mówi Żabski. Ingerując w ich świat, burzy porządek, ale jednocześnie tworzy przecież własne sacrum, nadaje przestrzeni swoją jednorodność. Mimo to gdy wśród pól rozlega się religijna pieśń, chłopi przystają w zadumie, Ślimak ściąga nawet czapkę z głowy. Wszystkich łączy wspólnota sakralnej w tym momencie czasoprzestrzeni. Stasiek, syn Ślimaka,

czuł potęgę ludzkich głosów. Zdawało mu się, że zza pagórka i zza rzeki płyną jakieś fale, które go obejmują niewidzialnymi ramionami i, niby pieszcząc, gwałtem ciągną do siebie [...]. Chłopi zdumieni przysłuchiwali się tej melodii, nieznanej im, a tak uroczystej. Po tęsknych i melancholijnych śpiewach w ich kościele wydawała się ona pieśnią jakiejś triumfującej potęgi. $(\mathrm{P}, 191)$

Niemcy-sąsiedzi są więc inni. Tę inność dla chłopów tworzą: terytorialny dystans, kulturowa odmienność, a nawet różnice w wyglądzie zewnętrznym lub sposobie zachowania ${ }^{15}$. Bielecki mówi, że mamy kłopot $\mathrm{z}$ innością. Honorata Gruchlik podkreśla, że kontakt z Innym jest utrudniony, ale nadal możliwy, perspektywa porozumienia z nim okazuje się w pełni realna. Inaczej sprawy się mają z Obcym. Z nim osiągnięcie konsensusu poprzez dialog zostaje wykluczone ze względu na dystans i niechęć kontaktu z nim.

O ile Inny to jednostka, która pod pewnymi względami różni się od nas, ale nie zagraża nam, naszej tożsamości czy naszemu poczuciu bezpieczeństwa, a - mówiąc językiem Gruchlik — jest sublokatorem, który nie walczy o bycie „takim samym”, o tyle Obcy nie tylko odróżnia się, lecz także wyłącza z grupy,

13 T. Żabski, Wstęp, [w:] B. Prus, Placówka..., s. XXXIII-XXXIV.

14 Z. Szweykowski, Twórczość Bolestawa Prusa, Warszawa 1972, s. 139.

${ }^{15}$ H. Gruchlik, Inność a obcość w kontekście filozoficznym, http://www.anthropos.us.edu.pl/ anthropos5/texty/gruchlik.htm [dostęp: 5.11.2018]. 
nie dopuszcza do zaistnienia jakichkolwiek związków z nią dopóty, dopóki nie dojdzie do jakiejś formy przysposobienia. „Wyraz »obcy« ewokuje niechęć, obawę, ostrożność, wrogość; kiedy ktoś lub coś pozostaje obcym, musi nastąpić jego odrzucenie, tak jak odrzuca się niepasujące do siebie elementy układanki" ${ }^{\prime \prime}$.

Niemcy - sąsiedzi — przestają być więc „obcy”, choć pozostają „inni”, wzajemne poznanie nie przyniesie asymilacji, aczkolwiek zagwarantuje zrozumienie i szacunek dla odmiennych kodów kulturowych, wyjątkowo często obecnych w rozważaniach Bolesława Prusa. Placówka w tym kontekście jest więc nie tyle kulminacją zainteresowań Prusa kwestiami sąsiedzko-narodowymi, ile staje się powieścią-otwarciem na obserwacje wzajemnych relacji i uwarunkowań kulturowych.

\section{Bibliografia}

Bachelard G., Wyobraźnia poetycka, Warszawa 1975.

Bednarek S., Wprowadzenie do semantyki ,inności”, http://www.khg.uni.wroc.pl/files/bednarekt. pdf.

Eliade M., Sacrum, mit, historia. Wybór esejów, Warszawa 1974.

Franko I., O literaturze polskiej, oprac. M. Kuplowski, Kraków 1979.

Gruchlik H., Inność a obcość w kontekście filozoficznym, http://www.anthropos.us.edu.pl/anthropos5/texty/gruchlik.htm.

Martuszewska A., Poetyka polskiej powieści dojrzałego realizmu (1876-1895), Wrocław 1977.

Mieletinski E., Poetyka mitu, Warszawa 1981.

Orzeszkowa E., Pisma zebrane, red. J. Krzyżanowski, Warszawa 1947-1953.

Prus B., Kroniki, oprac. Z. Szweykowski, Warszawa 1953-1970.

Prus B., Listy, oprac. K. Tokarzówna, Warszawa 1959.

Prus B., Placówka, oprac. T. Żabski, Wrocław 1987.

Prus B., Stówko o krytyce pozytywnej, [w:] idem, Pisma, t. 29. Studia literackie, artystyczne i polemiki, Warszawa 1950.

Szweykowski Z., Twórczość Bolesława Prusa, Warszawa 1972.

Tomicka J., Tomicki R., Drzewo życia. Ludowa wizja świata i człowieka, Warszawa 1975.

Tönnies F., Wspólnota i stowarzyszenie. Rozprawa o komunizmie i socjalizmie jako empirycznych formach kultury, Warszawa 1988.

Weintraub W., Wyznaczniki stylu realistycznego, „Pamiętnik Literacki” 52, 1961, nr 2.

${ }^{16}$ S. Bednarek, Wprowadzenie do semantyki ,,inności”, http://www.khg.uni.wroc.pl/files/bednarekt.pdf [dostęp: 15.06.2018]. 


\title{
Placówka by Bolesław Prus as a contribution to the characterization of neighbourly relations with Germany in the Kroniki of Bolesław Prus. Reconnaissance
}

\begin{abstract}
Summary
The article analyzes the Polish-German relations described by Bolesław Prus in Kroniki (Chronicles). It raises questions about how the author's personal beliefs determine the construction of his novel characters. The author has avoided the coloured chauvinism of complaints about the increasing number of German colonists coming to the cities and provinces. Prus was aware of threats, but also saw the advantages and strengths of German organizations. Observations of neighbours and international relations were used by Prus mainly for comparisons. Prus's chronicles and letters are a testimony to the sinusoidal variation of the author's moods: from intoxication with greatness and modernity to emotional depression.
\end{abstract}

Keywords: colonization, nation, relations, Germans, Polish people, borders 